\title{
Characterization and Valorization of Industrial Wastes (Molecular Sieves) in the Gas Complex of GP1/Z by BET and Surface Charge Method
}

\begin{abstract}
K.L Belarbi* AND M. HADJEL
Laboratory of Sciences Technology and Process Engineering LSTGP, Faculty of Chemistry, Department of Industrial Organic Chemistry, BP 1505 El Mnaouar Bir el Djir 31000 Oran Algeria

Industrial waste generates a supplementary cost for companies which must, by the force of law, take in charge their wastes, whether by their own means or through outside services. Molecular sieves used in the sections of dehydratation of natural gas become waste as soon as they are saturated and there is no possibility of regeneration. As a matter of fact, those of type $4 \AA$ are used in GP1/Z complex in Algerian company Sonatrach. Within the scope of this work the proposition to valorize these industrial wastes is put forward in the light of a series of analyses and experiments with distilled and polluted water. In this work a path is opened for further research valorization of the type $4 \AA$ saturated molecular sieves, used in the gas industry. After a simple wash with distilled water, we have noticed with the naked eye that our sample had changed color from black to white gray. We have repeated the same physical magnetism test, which was positive. We have carried a heat treatment at $100^{\circ} \mathrm{C}$ to remove physiosorbed water and $350^{\circ} \mathrm{C}$ heat treatment to remove the pore water. The surface area and $\mathrm{pH}$ of point of zero charge $\left(\mathrm{pH}_{\mathrm{PZC}}\right)$ of used zeolite were calculated as $37.54 \mathrm{~m}^{2} \mathrm{~g}^{-1}$ and 6 , respectively. The surface area and the $\mathrm{pH}$ of point of zero charge $(\mathrm{pH}$ PzC $)$ of unused zeolite were calculated as $6.965 \mathrm{~m}^{2} \mathrm{~g}^{-1}$ and 7 , respectively.
\end{abstract}

DOI: 10.12693/APhysPolA.131.545

PACS/topics: Molecular Sieves Waste, Valorize, Treatment, Analysis

\section{Introduction}

Utilized molecular sieves become waste and require burial in the soil. This fact had attracted our researcher curiosity. A sample of molecular sieves was analyzed by $\mathrm{X}$-ray florescence in order to know the elementary composition of the molecular sieves, then the analysis by X-ray ray diffraction $(\mathrm{XRD})$ was carried out to determine whether the structure of the molecular sieves has changed.

The structure of zeolites, from which the molecular sieves are made, consists of three-dimensional frameworks of $\mathrm{SiO}_{4}$ and $\mathrm{AlO}_{4}$ tetrahedra. The negative charge is balanced by the exchangeable cation $\left(\mathrm{Na}^{+}, \mathrm{K}^{+}\right.$, or $\left.\mathrm{Ca}^{2+}\right)$. These cations are exchangeable with certain cations of solutions.

This work is part of the preparation of the master thesis in management and environmental control. Molecular sieves are new and interesting adsorbers, which are currently available. There are several chemists who had worked with molecular sieves, K. Rida [1], C. Aparecida [2], M.J. Ahmed [3], J. Lad [4] and B. Zhang [5]. Our purpose is to revalorize used molecular sieves and to give them a second life. For that, two very important analyzes were employed, which are in direct relation with the adsorption and are related with the theory of Brunauer, Emmett and Teller (BET), which explains the physical adsorption of the gas molecule on a solid surface and allows the specific surface area to be measured. Several

*corresponding author; e-mail: belarbilamia@yahoo.fr researchers have studied the gas adsorption on molecular sieves [6-8] and the zero point charge (PZC) analysis, which expresses the acidic or basic character of a surface.

\section{Materials and methods}

The analysis of molecular sieves by RX florescence (XRF) was carried out using S8 Tiger spectrometer. Such analysis of a molecular sieve consists of sending X-rays, generated by a cathode ray tube, to the sample. These primary X-rays excite the atoms, which in turn emit secondary X-radiation, spectrum of which is analyzed by a spectrometer. Such spectrum is characteristic to the composition of the sample. By analyzing this spectrum, the elementary composition of the sample can be determined. Huber Guinier G 670 X-ray diffractometer was used for XRD analysis.

The samples were degassed under vacuum at $100^{\circ} \mathrm{C}$. After heat treatment [9] the analyzed material was crushed and sieved, to achieve grain size of $100 \mu \mathrm{m}$. Analysis based on Brunauer, Emmette and Teller (BET) theory was performed on a micrometer ASAP 2010 (data) 001245 SMP. This theory was verified for mesoporous solids and was extrapolated to microporous solids.

The point of zero charge (PZC) expresses the acidic or basic character of a surface. The PZC of the samples (the molecular sieves), used for the adsorption experiment, was determined by the so called $\mathrm{pH}$ drift process [10]. The $\mathrm{pH}$ of a deoxygenated dispersion $\left(\mathrm{N}_{2}\right.$ bubbling for $1 \mathrm{~h})$ of the adsorbent $(0.15 \mathrm{mg})$ in an aqueous solution of $\mathrm{NaCl}\left(50 \mathrm{ml}\right.$ at $\left.0.01 \mathrm{moll}^{-1}\right)$ was adjusted successively. Initial values were between 2 and 12 . The dispersions were stirred for 48 hours under $\mathrm{N}_{2}$ atmosphere and the 
final $\mathrm{pH}$ was measured and plotted as a function of the initial $\mathrm{pH}$. The $\mathrm{PZC} \mathrm{pH}$ is determined as the value for which the final $\mathrm{pH}$ equals to the initial $\mathrm{pH}$. $\mathrm{pH}$ of the solution is maintained using the solutions of $0.1 \mathrm{~N} \mathrm{NaOH}$ and $0.1 \mathrm{~N} \mathrm{HCl}$.

\section{Results and discussion}

RXF analysis has provided the elementary composition of the new and utilized molecular sieves, see Tables I and II. This data informs us, that studied molecular sieves can be classified as ordinary waste, since they contain no harmful elements. Therefore, it is possible to envisage a recycling procedure, which will include a specific nonexpensive treatment. The structure of the molecular sie-

TABLE I

Results of XRF analysis of unused molecular sieve.

\begin{tabular}{c|c|c}
\hline \hline Elements & $\begin{array}{c}\text { Mass fraction } \\
\text { of the oxide } \\
{[\%]}\end{array}$ & $\begin{array}{c}\text { Mass fraction } \\
\text { of the element } \\
{[\%]}\end{array}$ \\
\hline $\mathrm{Na}_{2} \mathrm{O}$ & 5.75 & 4.26 \\
$\mathrm{Al}_{2} \mathrm{O}_{3}$ & 34.8 & 18.4 \\
$\mathrm{SiO}_{2}$ & 56.9 & 26.6 \\
$\mathrm{P}_{2} \mathrm{O}_{5}$ & 0.42 & 0.18 \\
$\mathrm{~K}_{2} \mathrm{O}$ & 0.981 & 0.814 \\
$\mathrm{CaO}$ & 0.527 & 0.377 \\
$\mathrm{TiO}_{2}$ & 0.18 & 0.11 \\
$\mathrm{Fe}_{2} \mathrm{O}_{3}$ & 0.20 & 0.14 \\
\end{tabular}

TABLE II

Results of XRF analysis of used molecular sieve.

\begin{tabular}{c|c|c}
\hline \hline Elements & $\begin{array}{c}\text { Mass fraction } \\
\text { of the oxide } \\
{[\%]}\end{array}$ & $\begin{array}{c}\text { Mass fraction } \\
\text { of the element } \\
{[\%]}\end{array}$ \\
\hline $\mathrm{Na}_{2} \mathrm{O}$ & 4.43 & 3.29 \\
$\mathrm{Al}_{2} \mathrm{O}_{3}$ & 25.5 & 13.5 \\
$\mathrm{SiO}_{2}$ & 54.7 & 25.6 \\
$\mathrm{P}_{2} \mathrm{O}_{5}$ & 0.78 & 0.34 \\
$\mathrm{~K}_{2} \mathrm{O}$ & 1.02 & 0.844 \\
$\mathrm{CaO}$ & 3.30 & 2.36 \\
$\mathrm{TiO}_{2}$ & 0.312 & 0.187 \\
$\mathrm{Fe}_{2} \mathrm{O}_{3}$ & 4.41 & 3.08 \\
$\mathrm{MgO}^{\mathrm{SO}}$ & 1.78 & 1.07 \\
$\mathrm{SO}_{3}$ & 3.76 & 1.51
\end{tabular}

ves has not changed (Fig. 1) after usage. The crystal lattice of the molecular sieves remains the same.

\subsection{Unused zeolite}

The BET surface area report is as follows, BET surface area: $6.965 \pm 0.0221 \mathrm{~m}^{2} / \mathrm{g}$; slope: $0.618529 \pm 0.001967$; $y$-intercept: $0.006495 \pm 0.000254 ; C:$ 96.231617; VM: $1.599940 \mathrm{~cm}^{3} / \mathrm{g}$ STP; correlation coefficient: $9.99959 \times$ $10^{-1}$; molecular cross-section: $0.1620 \mathrm{~nm}^{2}$, as shown in Fig. 2.

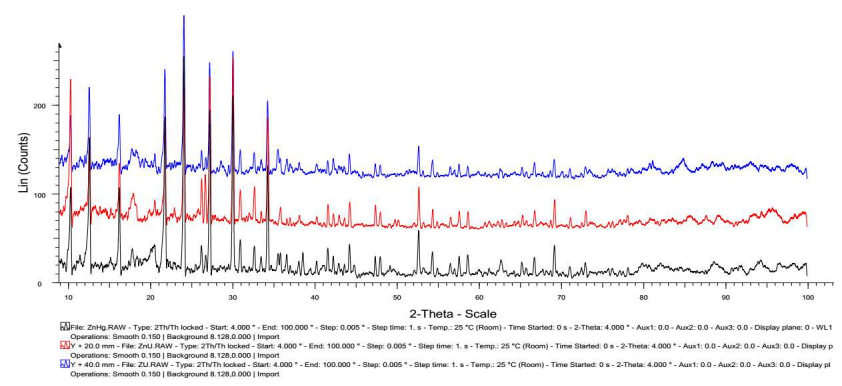

Fig. 1. X-rays diffraction of material of molecular sieve $4 \AA$, used, not used and refined.

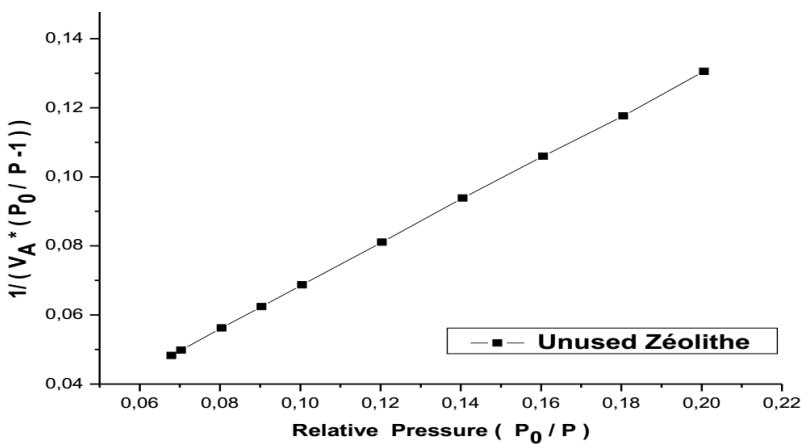

Fig. 2. BET surface area report of unused zeolite.

\subsection{Used zeolite}

The BET surface area report for the used zeolite is as follows, BET surface area: $37.54 \pm 0.1096 \mathrm{~m}^{2} / \mathrm{g}$; slope: $0.114325 \pm 0.000336 ; y$-intercept: $0.001630 \pm 0.000043$; $C:$ 71.123190; VM: $8.624045 \mathrm{~cm}^{3} / \mathrm{g}$ STP; correlation coefficient: $9.999655 \times 10^{-1}$; molecular cross-section: $0.1620 \mathrm{~nm}^{2}$, as shown in Fig. 3

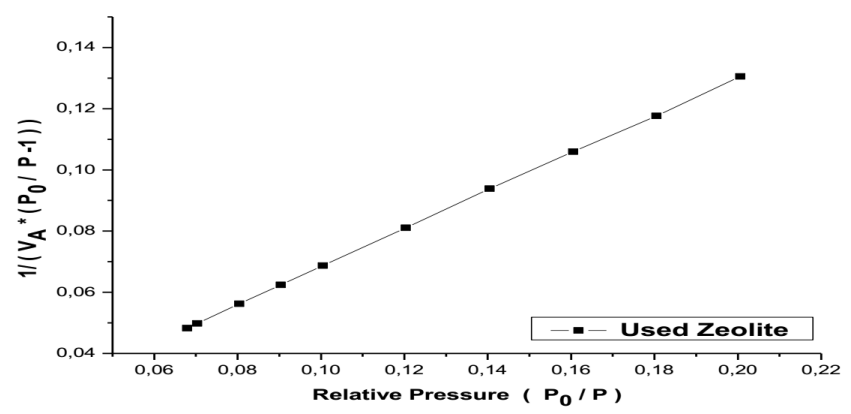

Fig. 3. BET surface area report of used zeolite.

The surface charge density $\left(\mathrm{C} / \mathrm{m}^{2}\right)$ is determined using the following equation [11]:

$$
\sigma=\left(C_{A}-C_{B}+\left[\mathrm{OH}^{-}\right]-\left[\mathrm{H}^{+}\right]\right) F / A m .
$$

Here $C_{A}$ and $C_{B}$ are the concentrations of acid and base needed to reach a point on the titration curve, in mol/l, $\left[\mathrm{H}^{+}\right]$and $\left[\mathrm{OH}^{-}\right]$are the concentrations of $\mathrm{H}^{+}$and $\mathrm{OH}^{-}$ converted from $\mathrm{pH}$, in $\mathrm{mol} / \mathrm{l}, F$ is the Faraday constant $(96490 \mathrm{C} / \mathrm{mol}), A$ is the specific surface area, in $\mathrm{m}^{2} / \mathrm{g}$, and $m$ is the concentration of used and unused zeolite, in $\mathrm{g} / \mathrm{l}$. 
The surface charge of used and unused zeolite, as function of solution $\mathrm{pH}$, is shown in Figs. 2 and 3. The titration curve illustrates that the surface charge decreases with the increase of $\mathrm{pH}$. The intersection of two curves with $\mathrm{pH}$ axis gives the point of zero charge $\left(\mathrm{pH}_{\mathrm{PZC}}\right)$, which was 6 for the used zeolite and 7 for the unused zeolite. In this study, at $\mathrm{pH}_{\mathrm{PzC}}$, the total charge from cations and anions on the sample surface is equal to zero. The surface charge is negative when the solution $\mathrm{pH}$ is above $\mathrm{pH}_{\mathrm{PzC}}$ and becomes positive when $\mathrm{pH}$ is below $\mathrm{pH}_{\mathrm{PZC}}$, as shown in Figs. 4 and 5.

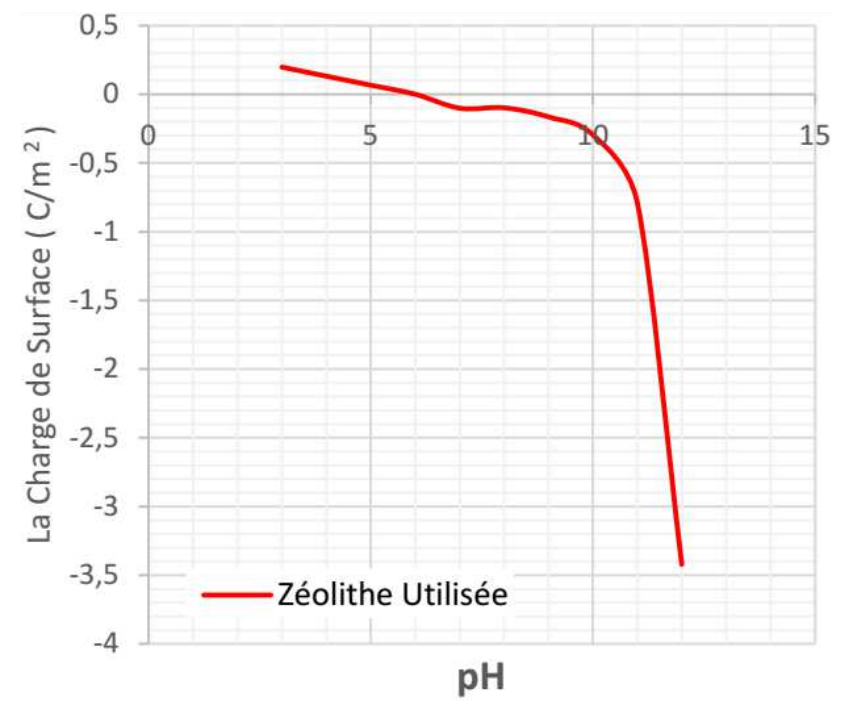

Fig. 4. Potentiometric titration curve of used zeolite.

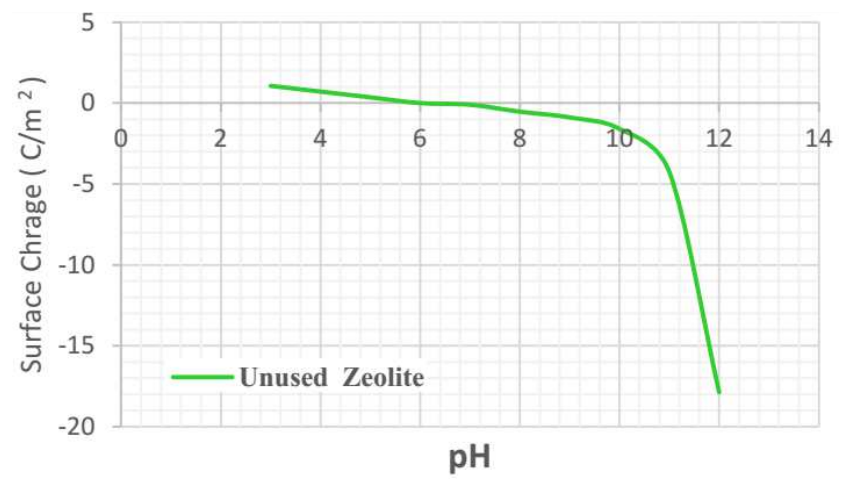

Fig. 5. Potentiometric titration curve of unused zeolite.

\section{Conclusions}

The waste material used in this study is a zeolite molecular sieve of type $\mathrm{A}$. It is an aluminosilica zeolite with structural formula of $\mathrm{Na}_{12}\left(\mathrm{AlO}_{2}\right)_{12}\left(\mathrm{SiO}_{2}\right)_{12} \cdot 27 \mathrm{H}_{2} \mathrm{O}$. The utilized molecular sieve is classified as the inert waste. It contains a large amount of water and a large amount of magnetite, which was proved during the characterization of this waste. XRD shows that this structure, is nothing other than aluminosilicate type A zeolite $4 \AA$. Our test sample is completely covered by a film of magnetite, which was determined by the physical test confirmed by chemical and physical XRF method. Our waste is considered inert and we can classify it as nonhazardous waste. The landfill at complex level is not dangerous. After simple washing of the sieves with the distilled water, we have carried out heat treatment at $100^{\circ} \mathrm{C}$, to remove physiosorbed water and heat treatment at $350{ }^{\circ} \mathrm{C}$ to remove the pore water. The surface area of used zeolite was calculated as $37.54 \mathrm{~m}^{2} \mathrm{~g}^{-1}$. The point of zero charge $\left(\mathrm{pH}_{\mathrm{PZC}}\right)$ was 6 for the used zeolite. The surface area of unused zeolite was calculated as $6.965 \mathrm{~m}^{2} \mathrm{~g}^{-1}$. The $\mathrm{pH}$ point of zero charge $\left(\mathrm{pH}_{\mathrm{PZC}}\right)$ was 7 for unused zeolite. These molecular sieves can be recycled for the purpose of the adsorption of the dyes, in order to prolong their operation.

\section{References}

[1] K. Rida, S. Bouraoui, S. Hadnine, J. Appl. Clay Sci. 83, 99 (2013).

[2] K. Aparecida Guimaraes Gusmao, L.V. Alves Gurgel, T.M. Savemento Melo, L.F. Gil, J. Environ. Manag. 118, 135 (2013)

[3] J.A. Muthanna, S.K. Theydan, J. Petroleum Sci. Eng. 108, 316 (2013).

[4] J. Lad, Y.T. Makkawi, J. Chem. Eng. 256, 335 (2014).

[5] B. Zhang, Y. Chen, L. Wei, Z. Zu, Microporous Mesoporous Mater. 156, 36 (2012).

[6] M.J. Ahmed, S.K. Theydan, J. Natural Gas Sci. Eng. 18, 1 (2014).

[7] C. Hua, W. Zong-Xin, Y.M. Sheng, G. Coold, Ener. Procedia 39, 208 (2013).

[8] C.A. Graude, V.M. Silva, C. Gigola, A.E. Rodrigues, Carbon 41, 2533 (2003).

[9] M.J. Wilson, in: A handbook of determinative methods in clay mineralogy, Chapman \& Hall, New York 1971 , p. 26.

[10] W.T. Tsai, H.C. Hsu, T.Y Su, K.Yu Lin, C. Ming Lin, T.H. Dai, J. Hazardous Mater. 147, 1056 (2007).

[11] F. Xie, C. Da, F. Zhang, J. Zhang, X. Han, Y. Ge, G. Li. Asian J. Chem. 25, 5759 (2013). 